morning of the fifth day it was found nearly dead, slight movements of the feet and abdomen being perceptible.

Harpalus caliginosus (Fabr.), beheaded at eleven and a half o'clock in the morning was alive at half past nine in the evening. It lived from fifteen to twenty hours.

Clytus robiniae Forster. After being beheaded it lived twenty-four hours.

Hylobius pales Herbst. After being beheaded it lived nearly three days.

Leptinotarsa decemlineata Say. On decapitation it lived two and a half days.

A. S. Packard, Jr.

\title{
The Effect of a Few Common Gases on Arthropods.
}

Carbonic Dioxide, $\mathrm{CO}_{2}$. This gas acted differently upon the several individuals, even of the same species. Coleoptera generally grew weak gradually, and became motionless in from eight to sixty seconds. Oniscus required a much longer time. Such insects as recovered did so slowly, appearing as if intoxicated and stiff in the joints. The following table will give an idea of the comparative time required for the stupefaction and recovery of a number of species of Coleoptera.

\begin{tabular}{|c|c|c|c|c|c|c|c|c|}
\hline \multicolumn{2}{|c|}{ Species. } & \multicolumn{3}{|c|}{ Motionless in } & \multicolumn{3}{|c|}{ Remained in Gas } & Recovered at end of \\
\hline Platy & tratus & & . $15 \mathrm{~s}$. & & . & - $1 \mathrm{~m}$. & & . $.5 \mathrm{~m}$. \\
\hline Ptero & s caudic & alis & $6 \mathrm{~s}$. & & • & $2 \mathrm{~m}$. & . & . $.10 \mathrm{~m}$. \\
\hline Stap & s maculc & sus & . $20 \mathrm{~s}$ & • & • & . $1 \mathrm{~m}$. & . & . . $2 \mathrm{~m} .30 \mathrm{~s}$. \\
\hline Cono & basalis & • & . $20 \mathrm{~s}$. & - & - & . $1 \mathrm{~m}$. & 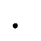 & . . $2 \mathrm{~m} .35 \mathrm{~s}$. \\
\hline “ & . . & - & . $20 \mathrm{~s}$. & - & . & - $1 \mathrm{~m}$. & - & - $\quad 3 \mathrm{~m} .35 \mathrm{~s}$. \\
\hline “6 & . . . & . & . $20 \mathrm{~s}$ & . & . & - $1 \mathrm{~m}$. & . & . . $4 \mathrm{~m} .20 \mathrm{~s}$. \\
\hline “ & . . . & . & . $20 \mathrm{~s}$. & • & • & . $1 \mathrm{~m}$. & . & . . $4 \mathrm{~m} .50 \mathrm{~s}$. \\
\hline “ & . . . & . & . $20 \mathrm{~s}$. & & . & . $1 \mathrm{~m}$. & . & . . $6 \mathrm{~m} .20 \mathrm{~s}$. \\
\hline 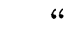 & . . . & . & . $20 \mathrm{~s}$ & & . & - $5 \mathrm{~m}$. & . & . . $11 \mathrm{~m}$. \\
\hline “ & . . . & . & . $20 \mathrm{~s}$. & & . & - $5 \mathrm{~m}$. & . & . . $12 \mathrm{~m}$. \\
\hline
\end{tabular}

Specimens of Oniscus, as may be seen by the following tabular statement, behaved very differently in this gas, nor could I discover any difference due to the adult or immature condition of the specimens. They were seized at first with twitchings of the limbs, then rolled up in their customary way, sometimes unrolled and rolled up again, finally became motionless, 
and if not left too long in the gas recovered with a similar but inverted order of symptoms. The annexed table will best illustrate this.

\begin{tabular}{|c|c|c|c|c|c|c|}
\hline & No. & $\begin{array}{l}\text { Twitchings } \\
\text { began at } \\
\text { end of }\end{array}$ & $\begin{array}{c}\text { Motionless } \\
\text { at } \\
\text { end of }\end{array}$ & $\begin{array}{l}\text { Remained } \\
\text { in } \\
\text { Gas }\end{array}$ & $\begin{array}{c}\text { Began } \\
\text { to move } \\
\text { again at end of }\end{array}$ & $\begin{array}{c}\text { Crawled } \\
\text { off at } \\
\text { end of }\end{array}$ \\
\hline & young & $1 \mathrm{~m}$. & $5 \mathrm{~m}$. & $10 \mathrm{~m}$. & $22 \mathrm{~m}$. & $50 \mathrm{~m}$. \\
\hline & adult & $1 \mathrm{~m} .30 \mathrm{~s}$. & $4 \mathrm{~m}$. & $5 \mathrm{~m}$. & $20 \mathrm{~m}$. & $25 \mathrm{~m}$. \\
\hline & young & $5 \mathrm{~m}$. & $8 \mathrm{~m}$. & $10 \mathrm{~m}$. & $25 \mathrm{~m}$. & $40 \mathrm{~m}$. \\
\hline & adult & $5 \mathrm{~m} .15 \mathrm{~s}$. & $50 \mathrm{~m}$. & $20 \mathrm{~m}$. & died & \\
\hline 5 & “ & $42 \mathrm{~s}$. & $8 \mathrm{~m}$. & $30 \mathrm{~m}$. & "6 & . \\
\hline 6 & " & $1 \mathrm{~m} .15 \mathrm{~s}$. & $20 \mathrm{~m}$. & $30 \mathrm{~m}$. & “ & \\
\hline 7 & 6 & $1 \mathrm{~m}$. & $9 \mathrm{~m}$. & $30 \mathrm{~m}$. & “ & \\
\hline 8 & $"$ & $1 \mathrm{~m} .15 \mathrm{~s}$. & $25 \mathrm{~m}$. & $30 \mathrm{~m}$. & “ & 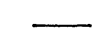 \\
\hline 9 & “ & $1 \mathrm{~m} .15 \mathrm{~s}$. & $13 \mathrm{~m}$. & $30 \mathrm{~m}$. & "6 & - \\
\hline 10 & 66 & $45 \mathrm{~s}$. & $4 \mathrm{~m}$. & $5 \mathrm{~m}$. & $45 \mathrm{~m}$. & $55 \mathrm{n}$ \\
\hline
\end{tabular}

Carbonic Dioxide, $\mathrm{CO}_{2}$, and Oxygen, $\mathrm{O}_{2}$. In a mixture of seventy-five parts by volume of carbonic dioxide and twentyfive parts of oxygen, a specimen of Anisodactylus lecontei Chd. was rendered motionless in thirty seconds, remained in the mixture three minutes, and recovered fully at the end of three and three quarters minutes. In a mixture of sixty-six parts of carbonic dioxide and thirty-four parts of oxygen, the following results were obtained.

\begin{tabular}{|c|c|c|c|}
\hline Species. & $\begin{array}{l}\text { Motionless } \\
\text { in }\end{array}$ & $\begin{array}{l}\text { Remained } \\
\text { in Gas }\end{array}$ & $\begin{array}{c}\text { Fully recovered } \\
\text { at end of }\end{array}$ \\
\hline caudicalis & $1 \mathrm{~m}$ & $5 \mathrm{~m}$ & . $7 \mathrm{~m}$. \\
\hline Elaterid larva . . & . $20 \mathrm{~m}$. & . $35 \mathrm{~m}$. & . $.37 \mathrm{~m}$. \\
\hline
\end{tabular}

Specimens of Oniscus treated with the latter mixture continued to move much longer than was usual with the same species when treated with pure carbonic dioxide, as the following table will show.

\begin{tabular}{|c|c|c|c|c|c|}
\hline No. & $\underset{\text { Bwitching }}{\text { Began }}$ & $\begin{array}{l}\text { Motionless } \\
\quad \text { in }\end{array}$ & $\begin{array}{l}\text { Remained } \\
\quad \text { in Gas }\end{array}$ & $\begin{array}{l}\text { Began to move } \\
\text { again at end of }\end{array}$ & $\begin{array}{l}\text { Crawled of } \\
\text { at end of }\end{array}$ \\
\hline 1 & $1 \mathrm{~m} .15 \mathrm{~s}$. & $25 \mathrm{~m}$. & $50 \mathrm{~m}$. & died & \\
\hline 2 & $2 \mathrm{~m}$. & $35 \mathrm{~m}$. & $50 \mathrm{~m}$. & " & - \\
\hline 3 & $1 \mathrm{~m} .45 \mathrm{~s}$. & $50 \mathrm{~m}$. & $50 \mathrm{~m}$. & $1 \mathrm{~h} .30 \mathrm{~m}$. & $3 \mathrm{~h} .10 \mathrm{~m}$ \\
\hline 4 & $\begin{array}{l}1 \mathrm{~m} .45 \mathrm{~s} . \\
2 \mathrm{~m} . \quad \text { kep }\end{array}$ & $\begin{array}{l}20 \mathrm{~m} . \\
\text { twitching }\end{array}$ & $\begin{array}{l}50 \mathrm{~m} . \\
50 \mathrm{~m} .\end{array}$ & $1 \mathrm{~h} .20 \mathrm{~m}$. & $\begin{array}{r}2 \text { h. } 50 \mathrm{~m} . \\
80 \mathrm{~m} .\end{array}$ \\
\hline
\end{tabular}


Carbonic Monoxide, CO. This gas, so poisonous to man, was tried on a few species of insects with the following results.

$\begin{array}{ccccc}\text { Species. } & \begin{array}{c}\text { Motionless } \\ \text { in }\end{array} & \begin{array}{c}\text { Remained } \\ \text { in Gas }\end{array} & \begin{array}{c}\text { Moving } \\ \text { again in }\end{array} & \begin{array}{c}\text { Flying or Crawling } \\ \text { at end of }\end{array} \\ \begin{array}{c}\text { Harpalus pensylvanicus } \\ \text { " }\end{array} & 20 \mathrm{~s} . & 10 \mathrm{~m} . & 11 \mathrm{~m} . & 18 \mathrm{~m} . \\ \text { Pieris rapae } & 15 \mathrm{~s} . & 1 \mathrm{~m} . & 1 \mathrm{~m} .30 \mathrm{~s} . & 3 \mathrm{~m} . \\ \text { " } & 8 \mathrm{~s} . & 1 \mathrm{~m} . & 1 \mathrm{~m} .30 \mathrm{~s} . & 2 \mathrm{~m} . \\ \text { " } & 18 \mathrm{~s} . & 5 \mathrm{~m} . & 5 \mathrm{~m} .10 \mathrm{~s} . & 5 \mathrm{~m} .45 \mathrm{~s} . \\ \text { " } & 1 \mathrm{~m} . & 10 \mathrm{~m} . & 10 \mathrm{~m} .10 \mathrm{~s} . & 14 \mathrm{~m} .30 \mathrm{~s} . \\ & 25 \mathrm{~s} . & 30 \mathrm{~m} . & 35 \mathrm{~m} . & 38 \mathrm{~m} .\end{array}$

I omitted, unfortunately, to note the sex of the Pieris rapae used, and sex may have considerable to do with the very different time required to prostrate the first two and the last two specimens. They all rubbed their probosces about their legs while recovering, and several of the species which were immersed in carbonic monoxide exhibited a slight tendency toward paralysis of the posterior limbs during recovery.

Hydrogen, $\mathrm{H}_{2}$. Pieris rapae was rendered motionless by immersion in the gas in thirty seconds. It was taken out at the end of five minutes, and began to move at the end of eight minutes. At the end of ten minutes it was flying in a weak manner. Harpalus caliginosus was rendered motionless in forty seconds, was removed in five minutes, moved its feet and antennæ at the end of six minutes, acted as if very weak for ten or twelve minutes more, but crawled off, apparently as well as ever, at the end of that time.

In a mixture of eighty parts of hydrogen and twenty parts of oxygen, and in a mixture of fifty parts of hydrogen and fifty parts of oxygen, Pieris rapae showed no signs of weakness at the end of thirty minutes.

Oxygen, $\mathrm{O}_{2}$. Silpha noveboracensis Forst. (S. marginalis Fab.) became slightly more active upon being placed in oxygen. The sexes copulated, and did not seem to be disturbed by the change of atmosphere. Staphylinus maculosus remained in oxygen three days without any apparent change in health or habits.

A spider placed in oxygen began to show signs of weakness in about forty minutes, and at the end of an hour was so weak as to be scarcely able to turn over when placed on its back. Upon removal to the air it soon recovered. 
Nitric Oxide, NO. Carabus serratus became unable to crawl the moment it was put in this gas, and in about ten seconds was perfectly motionless. It never recovered, although removed at the end of fifteen seconds. Oniscus never survived an immersion of forty to sixty seconds in this gas. All insects killed by nitric oxide became rigid, while the joints of those killed by carbonic dioxide were not stiffened.

It is quite evident from the preceding experiments that carbonic dioxide, alone or mixed with air, is poisonous to insects. Carbonic monoxide mixed with air was not tested, but probably is not poisonous, acting only by suffocation. This is the more likely on account of the similarity of its effects to those produced by hydrogen, which is not poisonous, as is shown by insects living in a mixture in which it was substituted for the nitrogen of the air. Again it is probable that carbonic monoxide, which poisons vertebrates by solidification of the red blood corpuscles and rendering them incapable of performing their work, would have no effect, except that of suffocation, on insects, whose respiration is performed by direct contact of the air with the muscles, without the intervention of blood corpuscles. Oxygen seems only to stimulate insects, although in some cases it may produce death in a short time. Nitric oxide evidently acts as a quick poison, from the action of which insects do not recover.

Geo. Dimmock.

\section{Proceedings of the Club.}

§ 13. Appendages homologous with Legs. When exhibiting a specimen of Dictyopteryx signata, which has two pairs of gills on the under side of the head, Dr. HAGEN said that Pictet figures the head of Nemura cinerea, which has two pairs of gills on the under side of the head and three on the thorax. Dr. Hagen considers the first two to represent or to be the remains of the legs belonging to the rings of the head. He said further, in connection with Dr. Packard's remarks, given below, that the female organs of Odonata are pleural (as are the legs); in Neuroptera and Hemiptera the female parts 

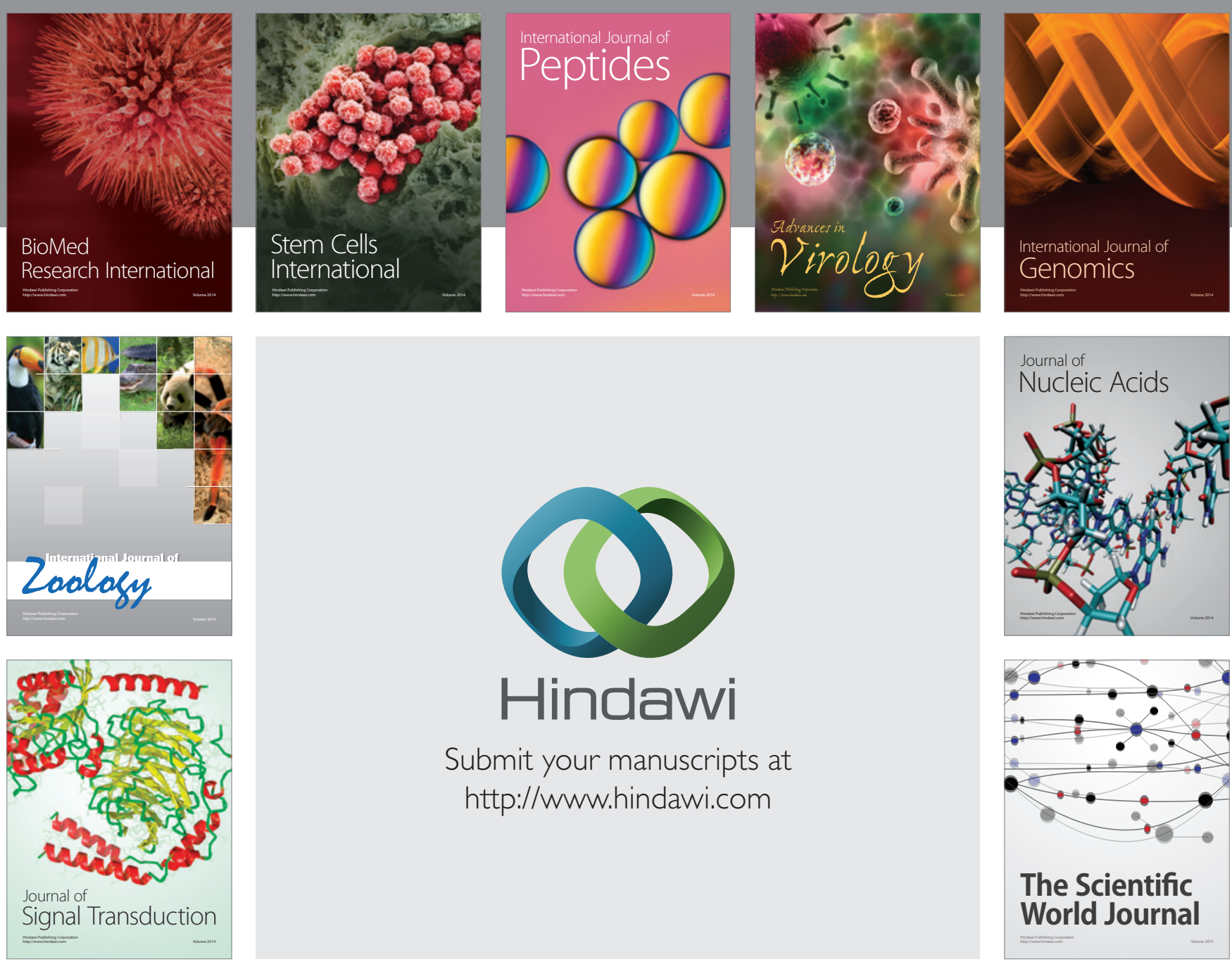

Submit your manuscripts at

http://www.hindawi.com
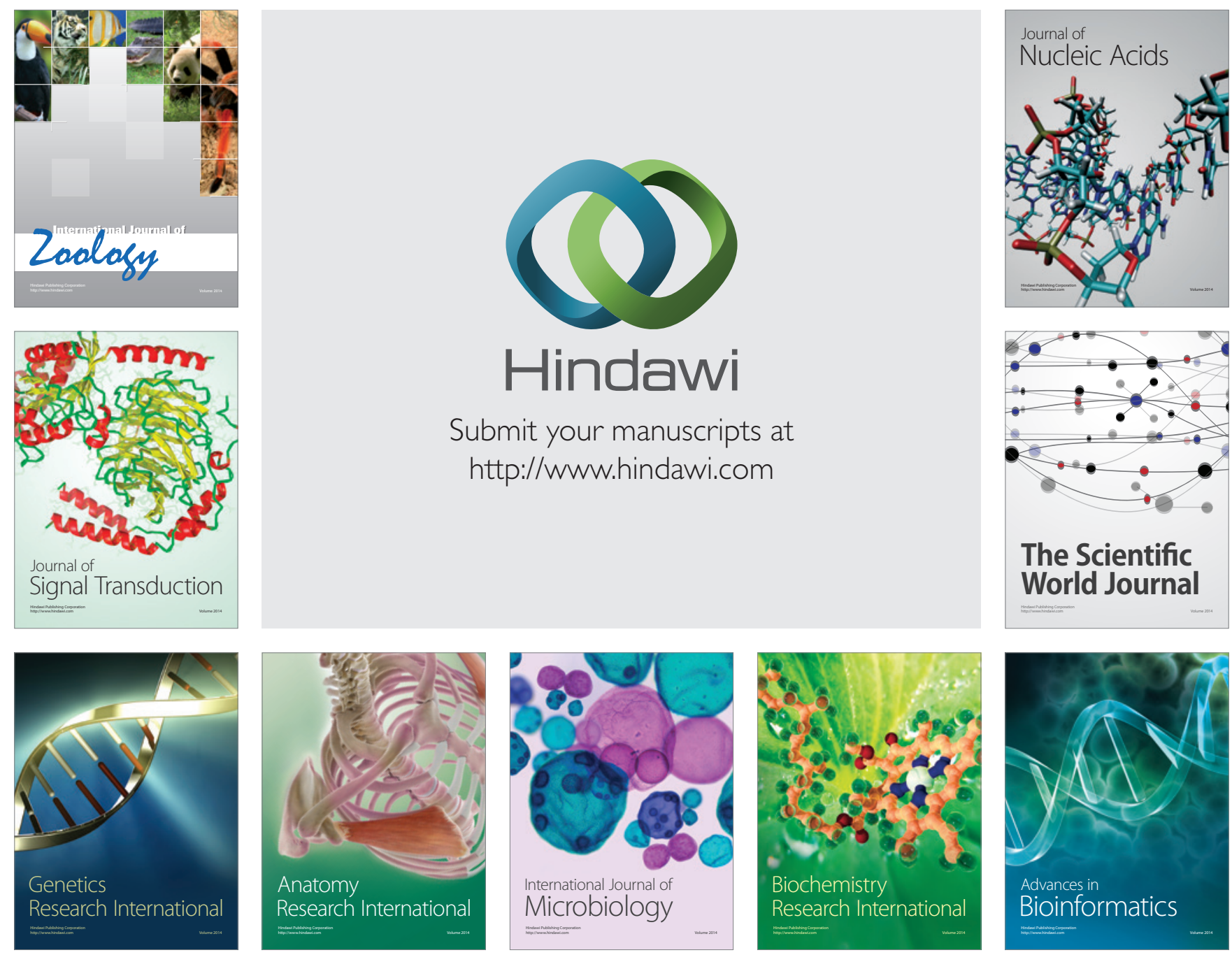

The Scientific World Journal
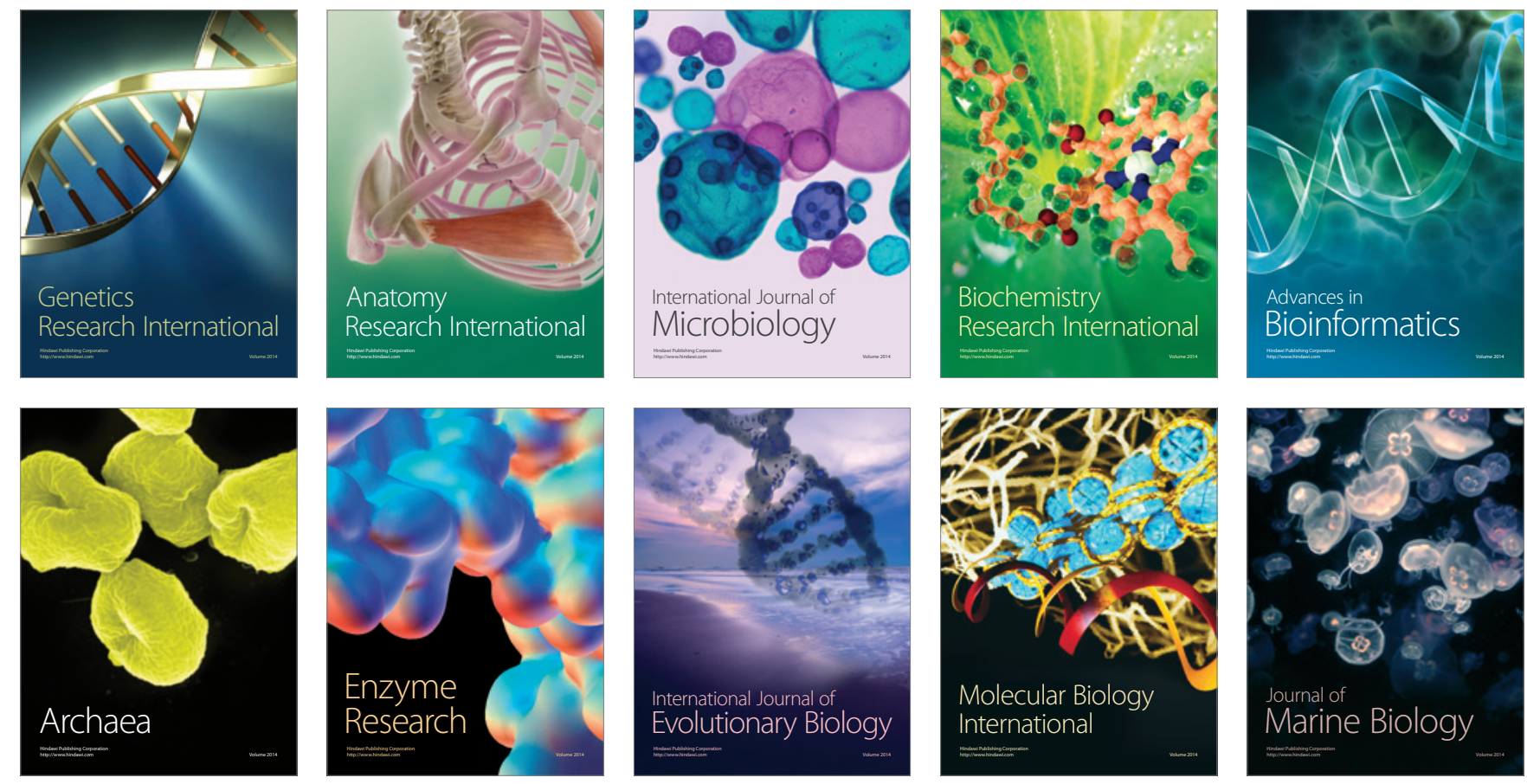